\title{
Spinel saturation of a PbO based slag as a method to mitigate the chemical degradation of magnesia- chromite bricks
}

\author{
L. Scheunis ${ }^{1}$, M. Campforts ${ }^{2}$, P.T. Jones ${ }^{1}$, B. Blanpain ${ }^{1}$ and A. Malfliet ${ }^{1}$ \\ ${ }^{1}$ Department of Materials Engineering, KU Leuven, Kasteelpark Arenberg 44, BE-3001 Leuven, Belgium \\ ${ }^{2}$ Research \& Development, Umicore, Watertorenstraat 33, BE-2250 Olen, Belgium
}

\begin{abstract}
For nonferrous smelters, the chemical wear of the magnesia-chromite bricks caused by the direct contact with the slag leads to regular replacement of the lining before complete failure. This is a costly and time intensive procedure. Increasing the lining's lifetime, by reducing the chemical wear, would result in a reduction of both the installation cost and the production losses. In this paper, the potential of changing the slag composition to limit the chemical dissolution rate by saturating the slag in spinel components is investigated by isothermal static finger tests. When saturating the slag in spinel by adding $\mathrm{Fe}_{2} \mathrm{O}_{3}$, a spinel layer forms at the interface between the refractory sample and the liquid slag. As the dissolution of $\mathrm{MgO}$ from the refractory in the slag is now controlled by solid state diffusion through the new spinel layer, the chemical wear rate is substantially decreased, thereby increasing the lifetime of the lining.
\end{abstract}

\section{Keywords}

Magnesia-chromite, refractory dissolution, $\mathrm{PbO}$ slag, slag engineering, chemical wear

\subsection{Introduction}

Magnesia chromite bricks are commonly used in the lining of smelters in the copper and lead industry $[1,2]$ because of their resistance against the thermal, mechanical and chemical loads inherent to the pyrometallurgical production process. Even despite these favorable properties, the bricks wear over time, eventually requiring a costly and time consuming replacement of the lining. The down time during the replacement of the lining leads to a significant production loss. To increase the profitability of the process, this down time needs to be minimized which, in turn, requires a reduction in the wear rate of the lining.

The wear of linings in pyrometallurgical processes is caused by a combination of thermo-mechanical and chemical degradation $[3,4]$. The wear mechanisms and rate differs for the bricks, depending if they are in contact with the gas, slag, matte or alloy phase. In the copper and the lead industry the chemical wear caused by the slag is typically the highest [1]. The interaction between the slag and the refractory can be classified in three different types: (1) the dissolution of refractory components into the liquid slag [5], (2) the formation of a solid solution based on components from the slag bath and 
the phases already present inside the refractory bricks [5-11] and (3) the formation of new solid phases $[7,12]$.

The chemical degradation can be reduced by changing the used brick type [6] but also by modifying the used slag. For the latter several strategies exist. The slag composition can be used to change the properties of the slag and thus indirectly influence the refractory wear. The viscosity of the slag system, for example, is a vital parameter controlling the lifetime of the refractory. Typically lower viscosity systems lead to faster wear rates [5]. The lower viscosity makes it easier for the slag to infiltrate the lining, exposing a larger part of the lining to reaction with the aggressive slag. In the copper industry, for example, the use of calcium ferrite slags allows an easier copper production compared to the classic fayalite slag system but the low viscosity of the slag leads to a significant increase in the wear rate of the lining, limiting the industrial use of this type of slag system. As an alternative, a ferrous calcium silicate slag can be used, which due to its higher viscosity, is less aggressive to the refractory lining [8].

A second method to limit the dissolution of refractory components is to add these components in the slag up to the saturation level of the components [13] or to change the slag composition to limit the solubility of the refractory components in the slag. Yan et al. [14], for example, studied the effect of the $\mathrm{pO}_{2}$ and $\mathrm{Cu}_{2} \mathrm{O}$ concentration on the $\mathrm{MgO}$ solubility in a calcium ferrite slag to select conditions that minimize the solubility of $\mathrm{MgO}$ and would therefore lead to a longer refractory life.

Besides the solubility of the refractory components into the liquid slag, the kinetics of the dissolution also control the lifetime of the lining. By forming a solid layer between the refractory phases and the liquid slag the dissolution rate of the former is lowered, leading to a longer lifetime of the lining. This is called indirect dissolution $[5,15]$. The continuation of the dissolution process can only take place when the refractory components diffuse through the newly formed solid layer. A process that is significantly slower than the diffusion through the liquid slag, towards the unsaturated bath.

The formation of a new phase depends on the composition of the slag and the composition of the used refractory brick. Not all newly formed phases, however, lead to a protective layer. Previous research $[16,17]$ has shown that the formation of a spinel layer between an $\mathrm{MgO}$ refractory brick and a CaO$\mathrm{Al}_{2} \mathrm{O}_{3}-\mathrm{SiO}_{2}-\mathrm{MgO}-\mathrm{FeO}$ slag can significantly reduce the dissolution rate of $\mathrm{MgO}$ into the bath.

The goal of this work is to determine if the saturation of a $\mathrm{PbO}-\mathrm{SiO}_{2}-\mathrm{CaO}-\mathrm{ZnO}-\mathrm{Al}_{2} \mathrm{O}_{3}$ slag in spinel forming components can be used as a method to slow down the chemical wear at the hot face of a magnesia-chromite brick. Such a slag forms during the 2 stage production of lead from sulfur containing ores. First the ores are oxidized in contact with air to form the slag, which, in a second stage, is reduced to form $\mathrm{Pb}[18,19]$. Because of the industrial importance of this slag system, the $\mathrm{PbO}^{-\mathrm{SiO}_{2}-}$ $\mathrm{CaO}-\mathrm{ZnO}-\mathrm{Al}_{2} \mathrm{O}_{3}-\mathrm{Fe}_{2} \mathrm{O}_{3}$ slag system has been extensively studied to determine the equilibrium phase relations and their composition [18, 20-23].

This goal is achieved by comparing the degradation for refractory samples in contact with two different slags: one without the addition of $\mathrm{Fe}_{2} \mathrm{O}_{3}$ and one with the addition of $\mathrm{Fe}_{2} \mathrm{O}_{3}$. The latter results in a spinel saturated liquid. In the paper we investigate if this spinel saturation leads to the formation of a protective spinel layer on the entire hot face of the sample and determine what the influence of this spinel layer on the chemical degradation is, by comparing the microstructure and $\mathrm{MgO}$ dissolution for both slags. To get the best possible insights into the reaction between the slag and the refractory sample, the interaction is tested on lab scale using synthetic systems allowing optimal control of the conditions during the experiment.

\subsection{Materials and methods}


Two different slags are used for the experiments. The selection of the used compositions is made using Figure 1. It gives the results of thermodynamic calculations, using FactSage 7.0 and its FTOxid database $[24,25]$, by varying the ratio of $\mathrm{Fe}_{2} \mathrm{O}_{3}$ to $\mathrm{ZnO}$ for fixed concentrations of $\mathrm{PbO}, \mathrm{SiO}_{2}, \mathrm{CaO}$ and $\mathrm{Al}_{2} \mathrm{O}_{3}$. The first slag composition is selected without the addition of $\mathrm{Fe}_{2} \mathrm{O}_{3}$ to the system. This composition is completely liquid at the experimental temperature $\left(1300^{\circ} \mathrm{C}\right)$. The second slag is selected to ensure the formation of a solid spinel phase together with the liquid phase. The formation of a spinel phase, with composition $\mathrm{AB}_{2} \mathrm{O}_{4}$ requires the presence of both divalent and trivalent cations. By varying the $\mathrm{ZnO}$ and $\mathrm{Fe}_{2} \mathrm{O}_{3}$ concentration in the slag, the ratio between divalent and trivalent cations in the slag is changed, resulting in a composition range (seen in Figure 1) where the liquid becomes (over)saturated in spinel. The experiments are performed in an alumina crucible. The first slag shown in Figure 1 , however, still has a high solubility of $\mathrm{Al}_{2} \mathrm{O}_{3} . \mathrm{Al}_{2} \mathrm{O}_{3}$ is therefore added to this slag to limit the crucible dissolution and thus the change in liquid composition caused by crucible dissolution during the experiment, while still staying in the fully liquid region. The used slag compositions are given in Table 1.

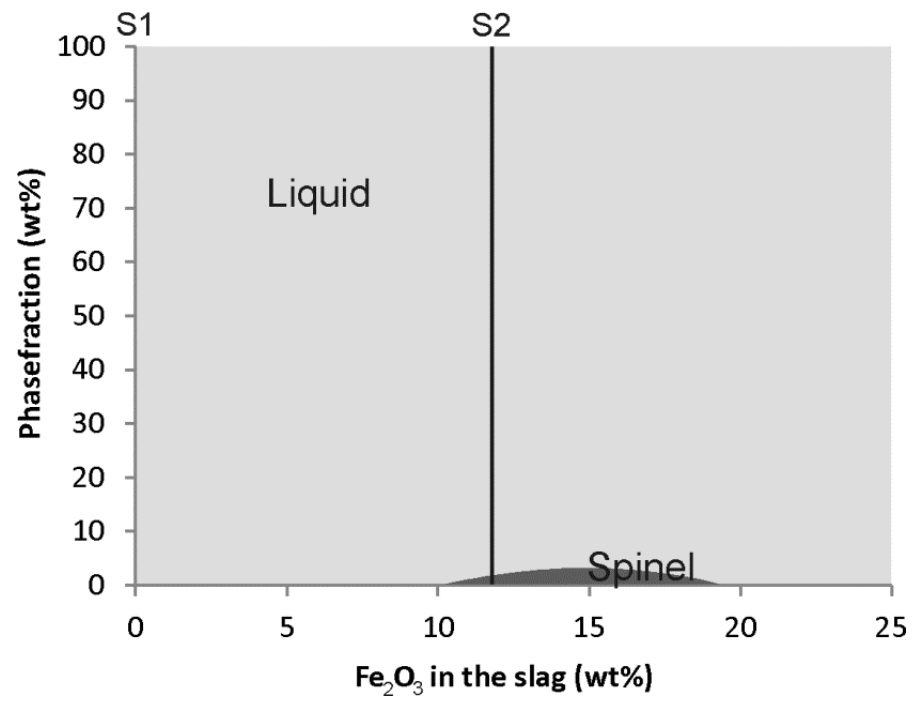

Figure 1: Equilibrium phase composition at $1300{ }^{\circ} \mathrm{C}$ and $\mathrm{pO} 2=0.21 \mathrm{~atm}$ for a slag with $58.2 \mathrm{wt} \% \mathrm{PbO}$, $14.6 \mathrm{SiO}_{2}, 0.9 \mathrm{wt} \% \mathrm{CaO}$ and $2.9 \mathrm{wt} \% \mathrm{Al}_{2} \mathrm{O}_{3}$. The remaining $23.4 \mathrm{wt} \%$ is the combination of $\mathrm{Fe}_{2} \mathrm{O}_{3}$ and $\mathrm{ZnO}$. The amount of $\mathrm{Fe}_{2} \mathrm{O}_{3}$ is varied between 0 and $23.4 \mathrm{wt} \%$ while $\mathrm{ZnO}$ shows the opposite trend (from 23.4 to $0 \mathrm{wt} \%)$. S1 and S2 are the 2 slag composition used in the experiments. They are selected to result in only a liquid (S1) and a liquid and spinel phase (S2). The figure is calculated using the FTOxid database from FactSage $7.0[24,25]$.

Table 1: Composition of the bulk slag (wt\%).

\begin{tabular}{|c|c|c|c|c|c|c|c|}
\hline Slag & & $\mathrm{PbO}$ & $\mathrm{SiO}_{2}$ & $\mathrm{CaO}$ & $\mathrm{ZnO}$ & $\mathrm{Fe}_{2} \mathrm{O}_{3}$ & $\mathrm{Al}_{2} \mathrm{O}_{3}$ \\
\hline S1 & Wt.\% & 55.2 & 13.8 & 0.9 & 22.1 & -- & 8.0 \\
\hline & Mole\% & 29.3 & 27.2 & 1.9 & 32.2 & -- & 9.3 \\
\hline
\end{tabular}




\begin{tabular}{|c|c|c|c|c|c|c|c|}
\hline S2 & Wt.\% & 58.2 & 14.6 & 0.9 & 11.7 & 11.7 & 2.9 \\
\hline & Mole\% & 34.1 & 31.8 & 2.1 & 18.8 & 9.6 & 3.7 \\
\hline
\end{tabular}

The experimental setup used during the experiments is schematically shown in Figure 2 . Prior to the experiment the refractory samples are cut in a bar shape $(20 \times 15 \times 100 \mathrm{~mm})$. For both experiments a commercially available fused grain rebonded magnesia-chromite brick is used. Magnesia-chromite bricks are commonly used in both copper and lead smelters [1, 2]. A detailed description of the microstructure and the composition of all present phases for the used refractory sample can be found in Scheunis et al. [26]. The synthetic slag is produced by mixing different pure oxide powders in the desired ratio, shown in Table 1. The mixture with a total weight of $1.5 \mathrm{~kg}$ is then added in a 1 liter alumina crucible and heated in an induction furnace at a rate of $600{ }^{\circ} \mathrm{C} /$ hour up to $1300{ }^{\circ} \mathrm{C}$. The refractory sample is heated in the same furnace with the alumina crucible but is only submerged when the slag has reached the desired experimental temperature. After 3 hour reaction time, the refractory sample is removed from the liquid bath and quenched in water to preserve the microstructure and the composition of the different phases in the best possible way. After the experiment the sample is cut using a diamond saw. The position of the cut is shown in Figure 2. After polishing the sample, its microstructure is analyzed using a fully quantitative EPMA-WDS (JEOL JXA-8530F) system operated using an acceleration voltage of $15 \mathrm{kV}$ and a probe current of $15 \mathrm{nA}$. The experimental findings are supported by thermodynamic calculations, using FactSage 7.0 and its FTOxid database [24, 25].

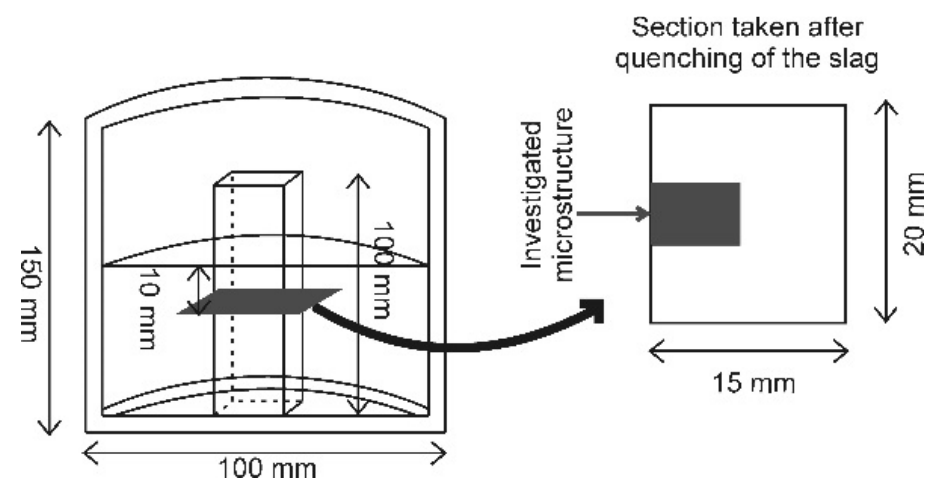

Figure 2: Schematic representation of the experimental procedure showing the high temperature experimental setup, removal of the sample and the position of the investigated microstructure.

\subsection{Results}




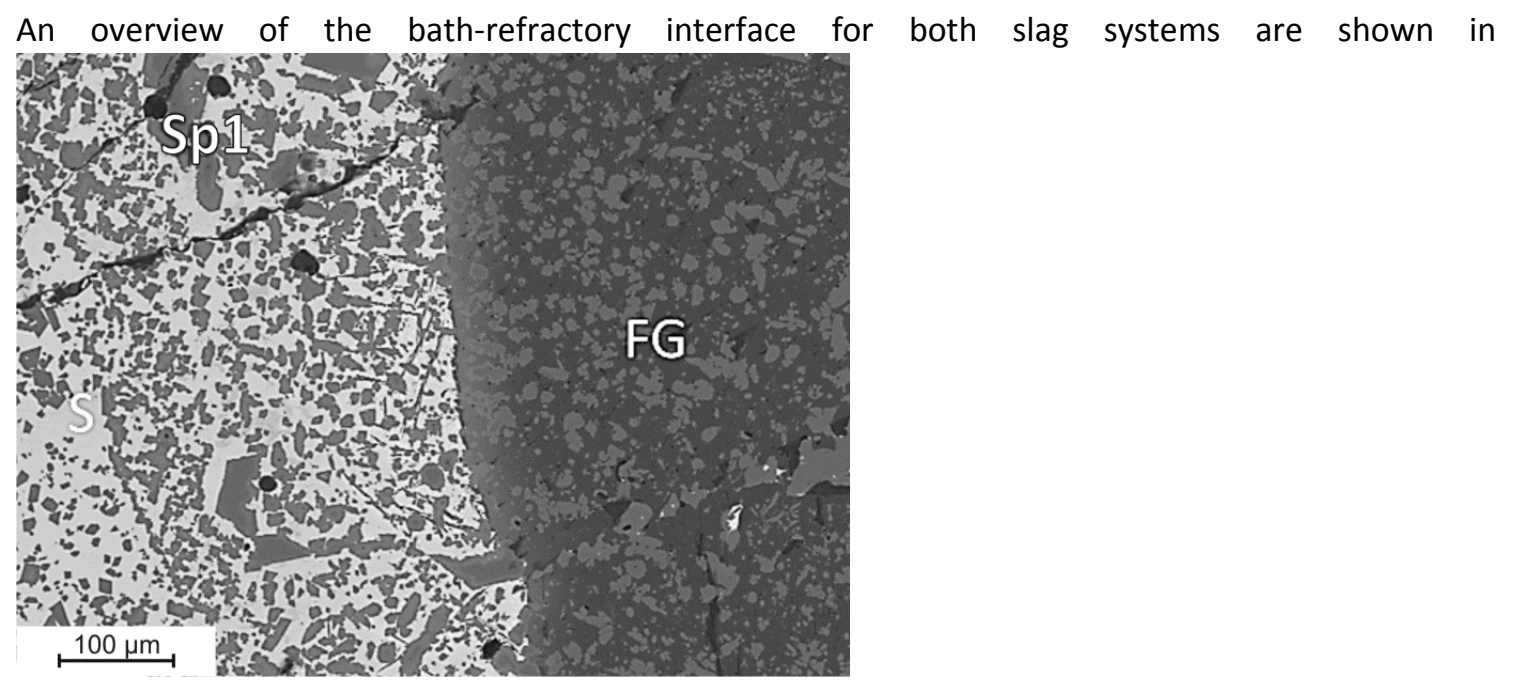

Figure 3 and Figure 4. Both show the presence of similar phases: the fused grain from the refractory sample, the liquid from the bath and solid spinel phases present in the liquid bath. To understand the difference in reaction caused by both slags, and thus the degradation mechanisms leading to failure, detailed images of the microstructure for each phase in the microstructure are analyzed and discussed below.



Figure 3: Hot face of the refractory sample after $3 \mathrm{~h}$ reaction time with the S1 slag. With S: slag, Sp1: spinel and FG: fused grain. The latter is a grain consisting of secondary chromite particles (Sp) in a periclase matrix. 




Figure 4: Hot face of the refractory sample after $3 \mathrm{~h}$ reaction time with the S2 slag. With S: slag, Sp2: spinel and FG: fused grain.

\subsubsection{Slag S1}

The slag composition S1 has been selected to ensure a contact between the liquid slag and the refractory sample without the formation of a protective spinel layer. There are insufficient trivalent cations in the slag to result in the formation of a spinel phase. The microstructure of the sample after

the experiment is shown in

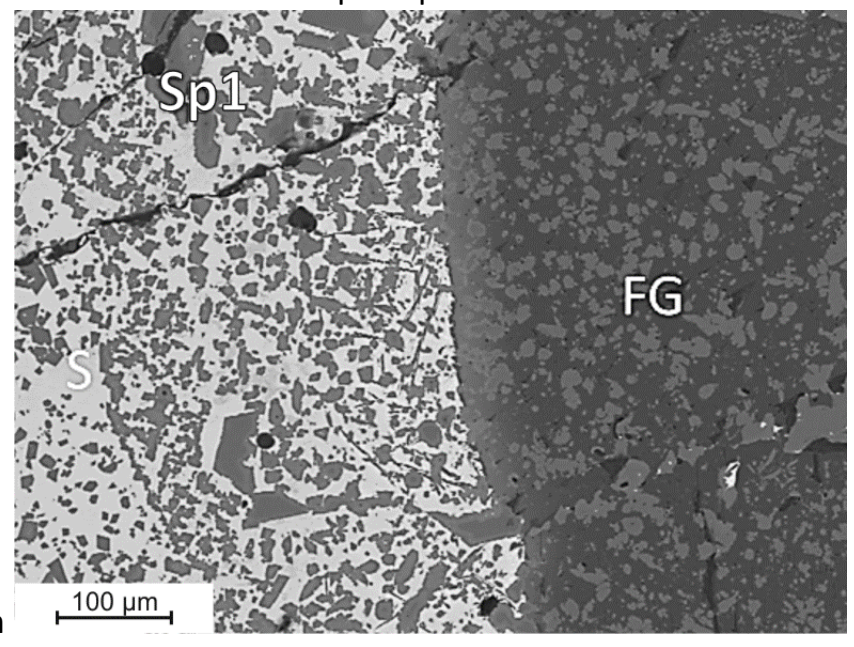

Figure 3. The bath is investigated in more detail in Figure 5, showing that it consists of an amorphous phase (indicated with S) which was most likely liquid during the experiment and several spinel particles (indicated with Sp1) in this liquid. The composition of these phases is analyzed using a linescan to determine the chemical composition every micrometer along a line, starting in the liquid phase and going over the spinel particle. The results are shown in Figure 6. The chemical composition of the rim of the spinel particle differs from the center. The center of the particle has the same chemical composition as a secondary chromite particle from the fused grain. The rim, on the other hand, has a composition enriched in $\mathrm{Al}_{2} \mathrm{O}_{3}$ and also contains $\mathrm{ZnO}$ as a new component. The $\mathrm{ZnO}$ is present deeper in the spinel particle than the $\mathrm{Al}_{2} \mathrm{O}_{3}$.

The interface between the bath and the refractory sample, called the hot face, is studied for both of the main grains present in the sample, namely primary chromite and fused grains. Figure 7 shows the interface between the bath and the fused grain. The line scan in Figure 8 shows the diffusion of ZnO 
from the slag into the periclase of the fused grain and the presence of a thin (less than 1 micron) forsterite layer between the periclase and the liquid bath. Also the secondary chromite present in the fused grains is measured in the linescan and contains $\mathrm{ZnO}$. For a primary chromite grain at the hot face, the microstructure is shown in Figure 9, and the chemical composition as a function of position is shown in Figure 10. As for the spinel particles present in the bath, the spinel composition again differs for the center and the rim in the primary chromite. The rim is enriched in $\mathrm{Al}_{2} \mathrm{O}_{3}$ and contains $\mathrm{ZnO}$ as a new component. The $\mathrm{ZnO}$ also has diffused deeper into the chromite spinel than the $\mathrm{Al}_{2} \mathrm{O}_{3}$.

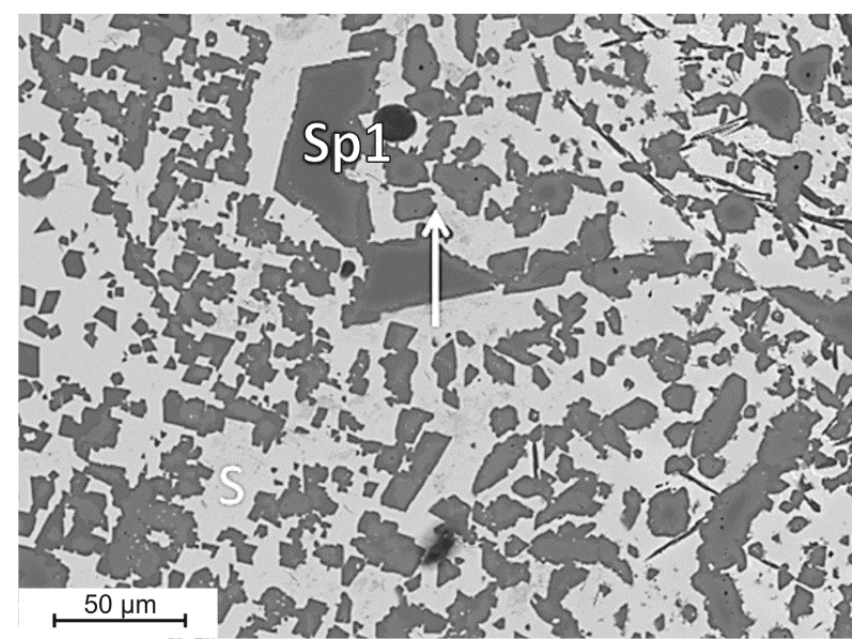

Figure 5: Detailed image of the microstructure of the bath after reaction with slag S1, showing the spinel phases (Sp1) in a glass phase which was liquid slag (S) at high temperature. The arrow indicates the position of a linescan, over which the chemical composition of the different phases was measured.

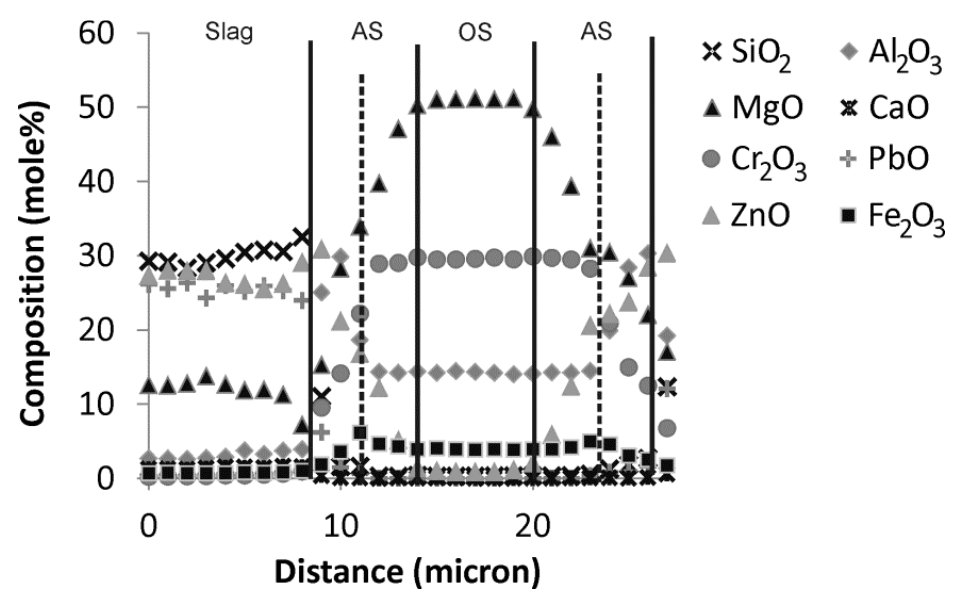

Figure 6: Chemical composition along the arrow indicated in Figure 5. The full lines indicate the transition between the different phases: slag, the original spinel structure (OS) and the modified part of the spinel (AS). The dotted line givens the transition between the modified part of the spinel enriched in $\mathrm{Al}_{2} \mathrm{O}_{3}$ and the part having the same $\mathrm{Al}_{2} \mathrm{O}_{3}$ content as the original spinel. 




Figure 7: Detailed image of the microstructure at the interface between the bath and a fused grain from the refractory sample after reaction with slag S1, showing the spinel phases (Sp1) in a glass phase which was liquid slag (S) at high temperature and the fused grain consisting of periclase (P) and secondary chromite (SC). The arrow indicates the position of a linescan, over which the chemical composition of the different phases was measured.

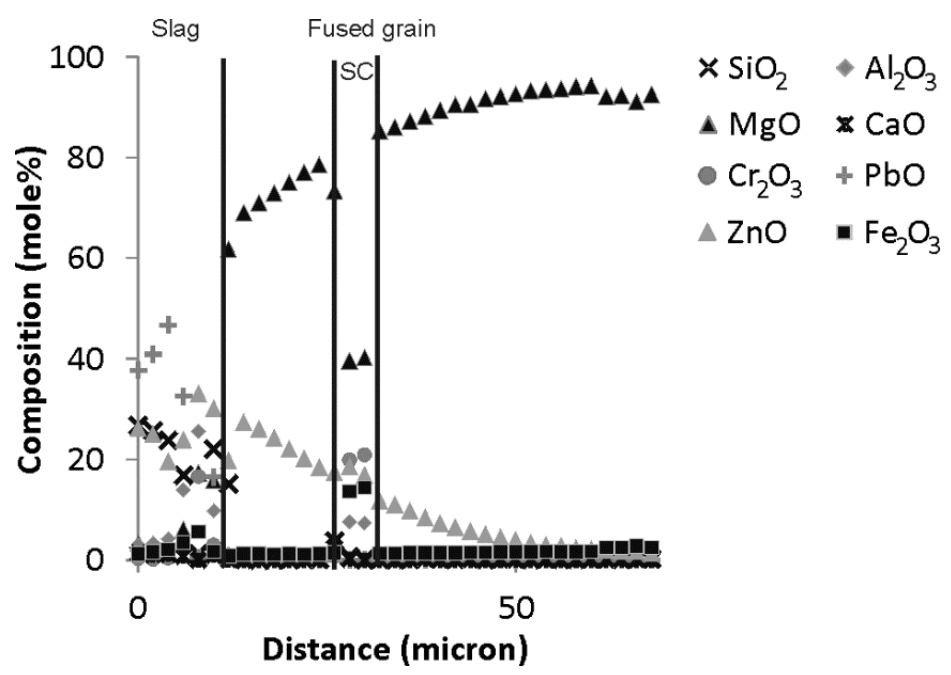

Figure 8: Chemical composition along the arrow indicated in Figure 7. The full lines indicate the transition between the different phases. The fluctuating composition at the interface between the slag and the fused grain is caused by the presence of both a small spinel particle Sp1 in front of the hot face and a thin forsterite layer adhered on the fused grain with in between a thin layer of liquid. The linescan also cut across a secondary chromite particle (SC). 




Figure 9: Detailed image of the microstructure at the interface between the bath and a primary chromite spinel from the refractory sample after reaction with slag S1, showing the spinel phases (Sp1) in a glass phase which was liquid slag (S) at high temperature and the fused grain (FG) and primary chromite (PC) of the refractory. The arrow indicates the position of a linescan, over which the chemical composition of the different phases was measured.

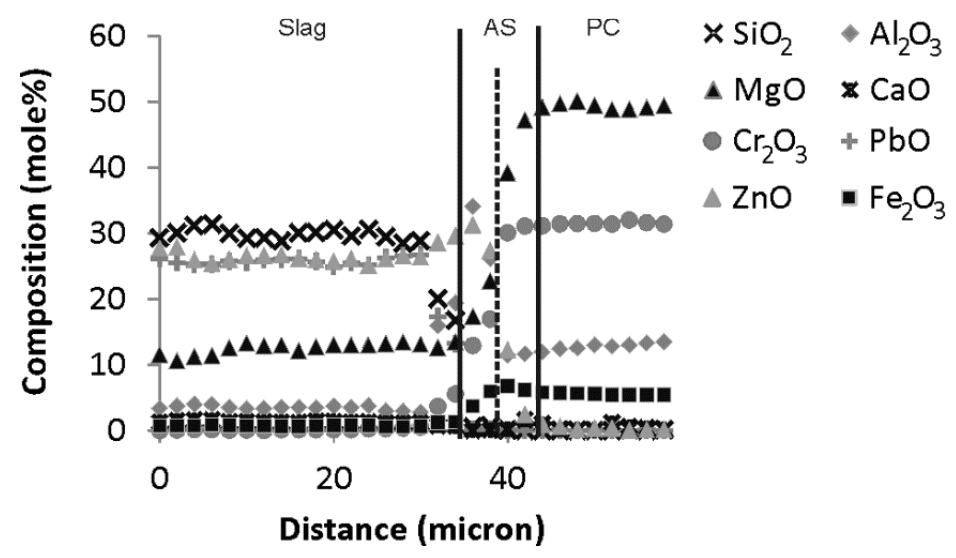

Figure 10: Chemical composition along the arrow indicated in Figure 9. The full lines indicate the transition between the different phases: slag, the original primary chromite spinel (PC) and the modified part of the spinel (AS). The dotted line givens the transition between the modified part of the spinel enriched in $\mathrm{Al}_{2} \mathrm{O}_{3}$ and the part having the same $\mathrm{Al}_{2} \mathrm{O}_{3}$ content as the primary chromite.

\subsubsection{Slag S2}


The microstructure after reaction for the slag S2 is given in Figure 4. It shows similar phases as for the

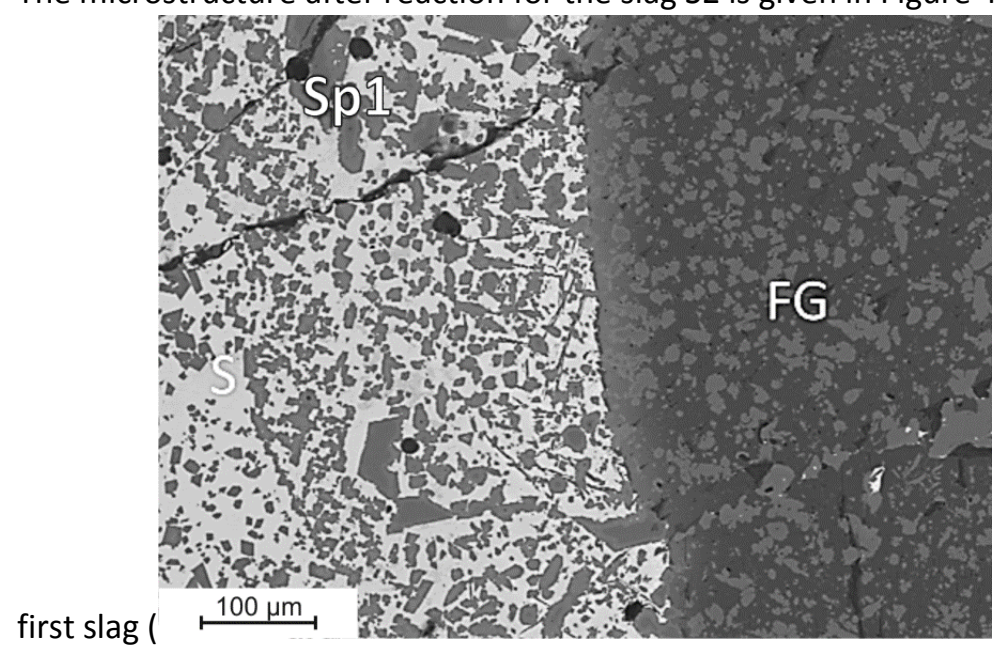

Figure 3): the fused grain for the refractory sample, an amorphous phase which was liquid at high temperature and the spinel particles in the liquid phase. The difference with the first slag is the formation of a spinel layer between the bath and the refractory sample, which is indicated in Figure 4 with SpL. The same analyses as for the first slag are performed: a detailed view of the microstructure and chemical composition of the different phases.

Figure 11 shows a detailed view of the microstructure of the bath. A linescan of the chemical variation over the spinel particle in the bath shows that the spinel particles (indicated with Sp2 in Figure 11) have a very homogenous composition, consisting mostly out of $\mathrm{ZnO}, \mathrm{Al}_{2} \mathrm{O}_{3}$ and $\mathrm{Fe}_{2} \mathrm{O}_{3}$.

Figure 13 shows the formation of a solid spinel layer (indicated with SpL) on top of the fused grain at the interface between the latter and the liquid bath. The chemical composition over this layer, shown in Figure 14, shows that the composition of this spinel phase is similar as to that of the spinel particles in the bath. The main difference between both is the diffusion profile in $\mathrm{MgO}$ over the spinel layer, going down the periclase of the refractory sample to the liquid bath. $\mathrm{ZnO}$ also shows a diffusion profile but has the opposite trend as the MgO.

The interaction between a primary chromite grain and the slag S2 is shown in Figure 15 and Figure 16. The rim of the chromite spinel has a different composition than its center. Specifically the presence of $\mathrm{ZnO}$ and enrichment in $\mathrm{Fe}_{2} \mathrm{O}_{3}$ are noted. 


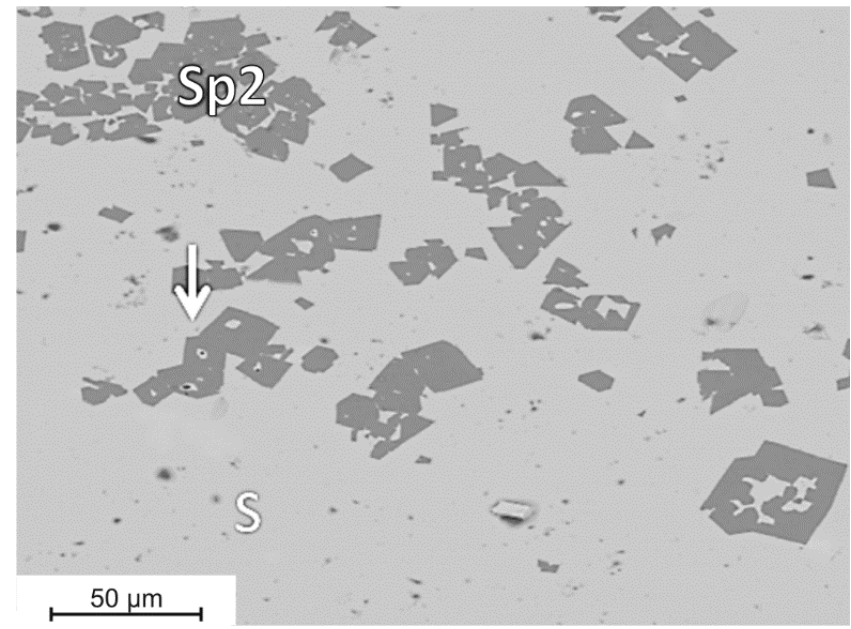

Figure 11: Detailed image of the microstructure of the bath of slag S2, showing the spinel phases (Sp2) in a glass phase which was liquid slag (S) at high temperature. The arrow indicates the position of a linescan, over which the chemical composition of the different phases was measured.

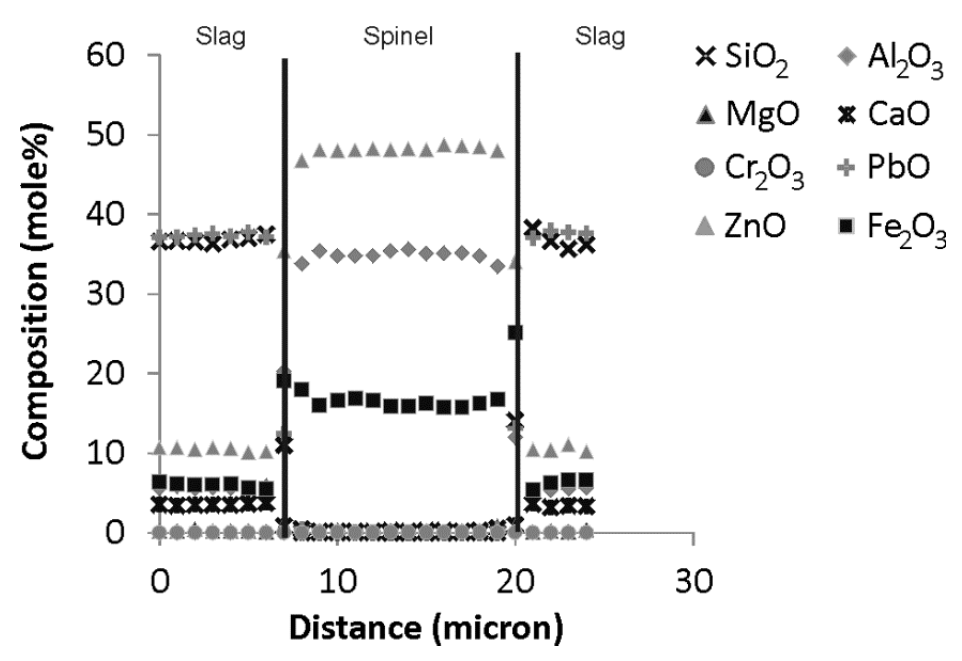

Figure 12: Chemical composition along the arrow indicated in Figure 11. The lines indicate the transition between the different phases: slag and spinel. 


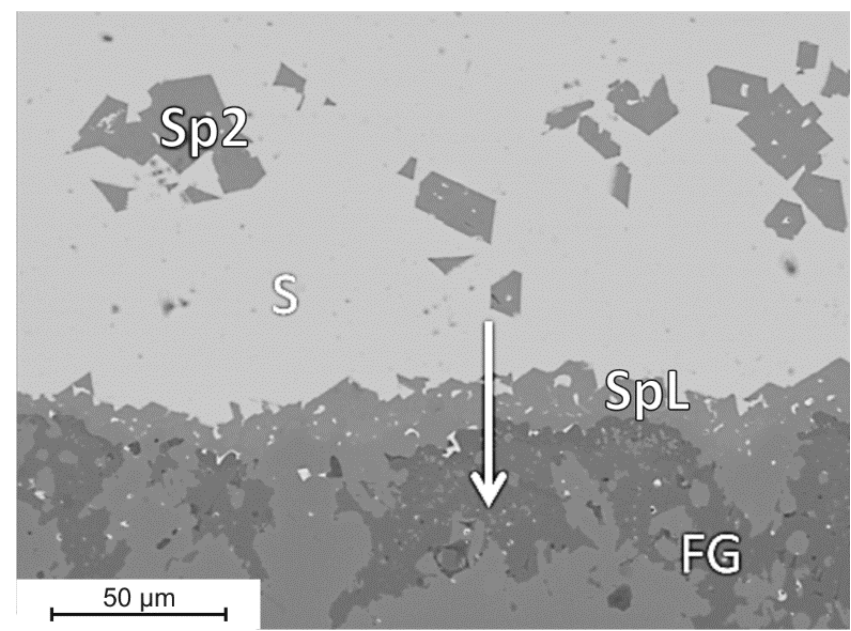

Figure 13: Detailed image of the microstructure at the interface between the bath and a fused grain from the refractory sample after reaction with slag $\$ 2$, showing the spinel phases (Sp2) in a glass phase which was liquid slag (S) at high temperature and the fused grain (FG). The arrow indicates the position of a linescan, over which the chemical composition of the different phases was measured.

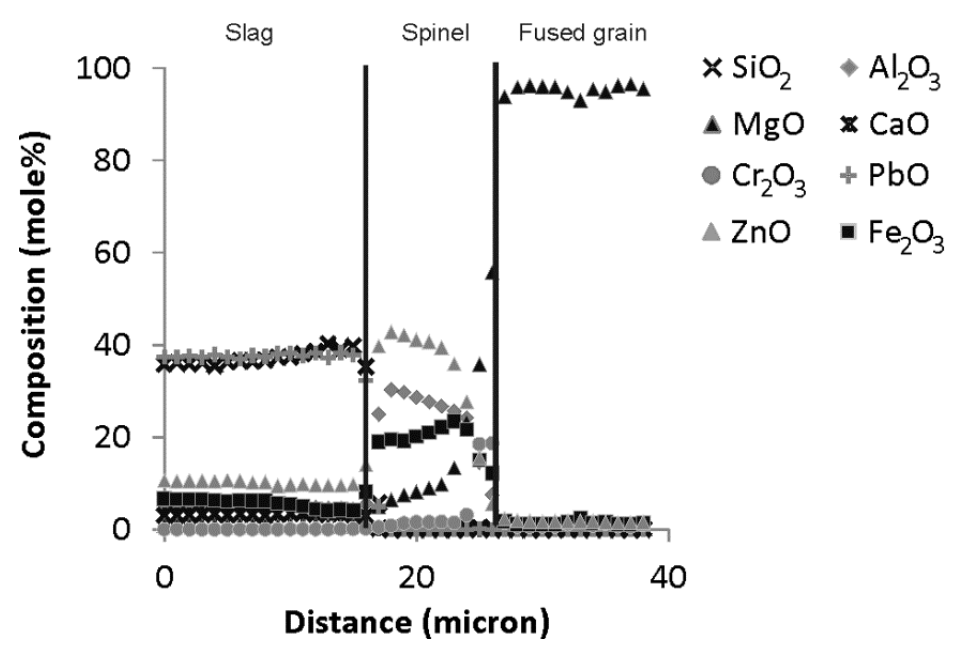

Figure 14: Chemical composition along the arrow indicated in Figure 13. The lines indicate the transition between the different phases: slag, spinel and fused grain. 


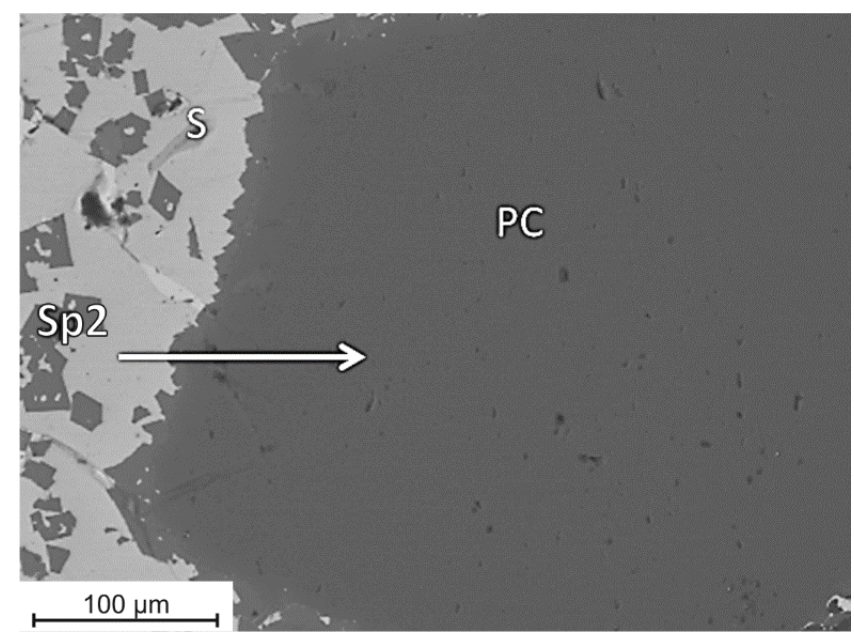

Figure 15: Detailed image of the microstructure at the interface between the bath and a primary chromite spinel from the refractory sample after reaction with slag S2, showing the spinel phases (Sp2) in a glass phase which was liquid slag (S) at high temperature and a primary chromite (PC) grain of the refractory. The arrow indicates the position of a linescan, over which the chemical composition of the different phases was measured.

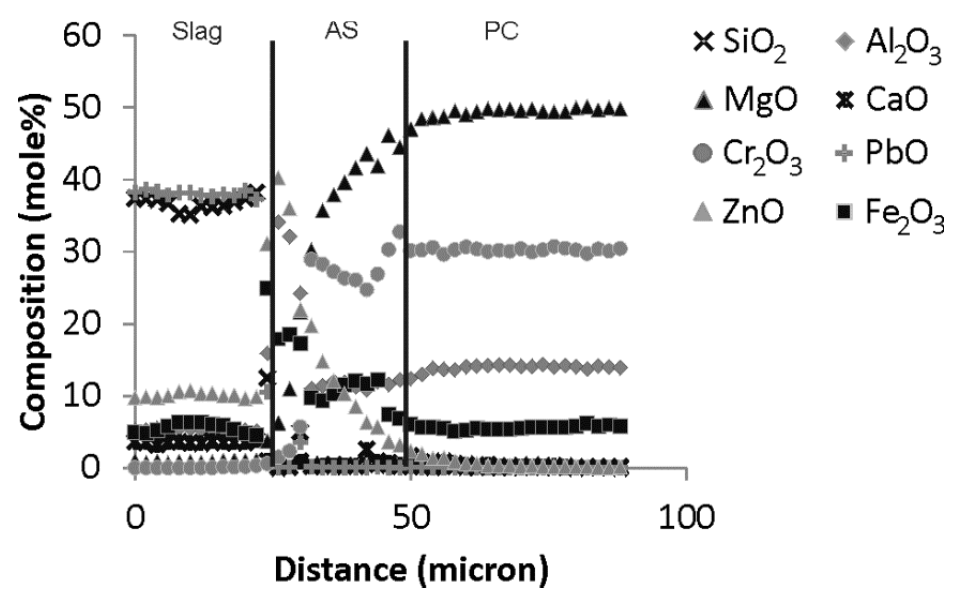

Figure 16: Chemical composition along the arrow indicated in Figure 15. The lines indicate the transition between the different phases: slag, the original primary chromite spinel (PC) and the modified part of the spinel (AS).

\subsection{Discussion}

\subsubsection{Microstructural differences between the samples from slag S1 and S2}

By comparing the microstructure of the samples after the test with respectively slag S1 and S2, three main differences can be found which can be related to the difference in slag composition. The first difference is the nature of the spinel particles floating in the liquid at the hot face of the sample. In the slag S1, the center of the spinel particles has the same composition as the secondary spinel particles originating from the refractory, whereas the rim of these particles is enriched in the slag components $\mathrm{Al}_{2} \mathrm{O}_{3}$ and $\mathrm{ZnO}$ (Figures 5 and 6). Although the slag $\mathrm{S} 2$ also has spinel particles inside the liquid at the hot face of the sample, they have a different composition than the secondary spinel grains (Figures 11 
and 12). Most noteworthy is the lack of chromium in these phases. Because $\mathrm{Cr}_{2} \mathrm{O}_{3}$ is also not detected in the liquid it is unlikely that these spinel grains are reacted secondary chromite spinel particles. They are an equilibrium phase formed in the slag. The second difference is the MgO concentration in the liquid phase around the floating spinel particles. As can be seen in Figure 6, the dissolved MgO in this liquid is around 12 mole\% for the test with slag S1, whereas it is in the order of 1 mole\% for the test with slag S2. The final difference is the formation of a spinel layer at the hot face of the refractory between the fused grains and the liquid phase in the case of the test with the slag S2 (Figure 13), which was absent in the sample from the test with the slag S1 (Figure 7).

These differences are visualized in Figure 17. The next section is devoted to explain the observed differences and the phenomena summarized in Figure 17 through the effect the slag composition has on the phase equilibria.



Figure 17: schematic comparison of the interaction between the refractory and respectively the slag S1 (unsaturated in spinel) and S2 (saturated in spinel with additional formation of Al2O3-rich spinel due to dissolution of the $\mathrm{Al}_{2} \mathrm{O}_{3}$ from the crucible). The occurring phenomena from the reaction between the slag and the refractory are indicated, with the numbers indicating their order of appearance. For slag $\mathrm{S1}$, the dissolution of $\mathrm{MgO}$ leads to enhanced refractory wear, which is mitigated in the spinel saturated slag S2 due the formation of a protective spinel layer. 


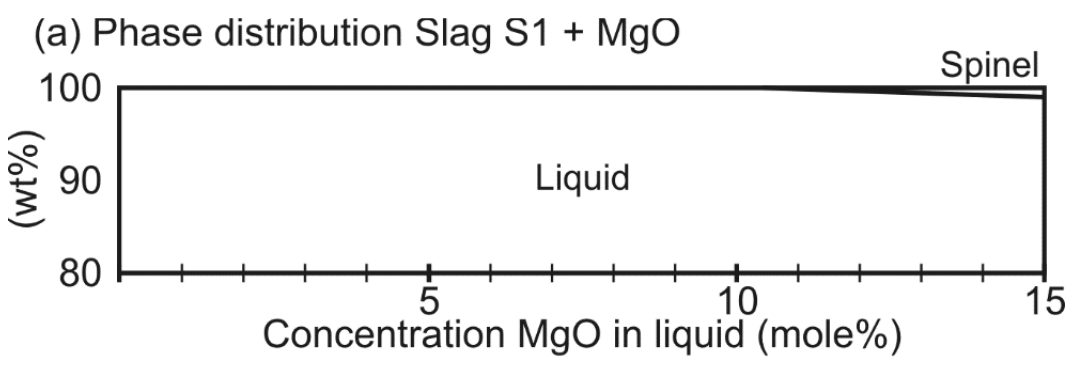

(b) Phase distribution Slag S2 + MgO

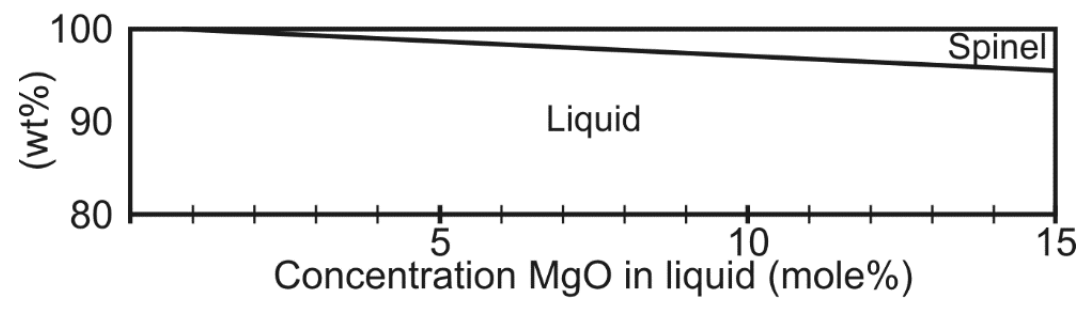

Figure 18: Factsage calculations to reveal the difference in slag composition on the formation of spinel through contact with $\mathrm{MgO}$. For these calculations, $20 \mathrm{~g} \mathrm{MgO}$ has been added to $100 \mathrm{~g}$ slag at $1300{ }^{\circ} \mathrm{C}$. For S1, the slag composition from Table 1 has been used. For S2, the composition as measured on the amorphous phase was taken, as this is the composition of the liquid phase in contact with $\mathrm{MgO}$ upon the experiment.

\subsubsection{Effect of slag composition on the phase equilibria}

\subsubsection{Slag S1}

According to FactSage calculations using the composition of S1 in Table 1, the slag S1 is completely liquid at $1300{ }^{\circ} \mathrm{C}$. Besides minor changes in $\mathrm{Al}_{2} \mathrm{O}_{3}$ content due to dissolution of the crucible, the main changes in slag composition, and thereby the phase equilibria in the slag, are caused by the interaction between the slag and the refractory. The interaction between the slag S1 and the refractory is mainly characterized by the dissolution of $\mathrm{MgO}$ from the refractory into the liquid bath, as can be recognized through the presence of about 12 mole\% MgO in the amorphous phase of the slag S1 (Figure 6). This value has also been predicted by FactSage calculations to be the concentration of $\mathrm{MgO}$ in the liquid slag phase at which spinel phase starts to form (Figure 18a).

The result of this high solubility of $\mathrm{MgO}$ is that the periclase matrix of the fused grains easily dissolves. The secondary chromite spinel particles, that are originally present inside the periclase, now come into contact with the bath, where they start to react with the liquid slag. The result of this reaction is the formation of the spinel rim with a different composition(Figures 5 and 6). The enrichment in $\mathrm{Al}_{2} \mathrm{O}_{3}$ and $\mathrm{ZnO}$ is due to the following reaction:

$\mathrm{Al}_{2} \mathrm{O}_{3, \text { slag }}+\mathrm{ZnO}_{\text {slag }}+\mathrm{Mg}[\mathrm{Cr}, \mathrm{Al}, \mathrm{Fe}]_{2} \mathrm{O}_{4, \text { refractory }} \rightarrow[\mathrm{Zn}, \mathrm{Mg}][\mathrm{Al}, \mathrm{Cr}, \mathrm{Fe}]_{2} \mathrm{O}_{4}$

Figure 6 shows that the $\mathrm{ZnO}$ enrichment occurs deeper inside the secondary spinel phase than the $\mathrm{Al}_{2} \mathrm{O}_{3}$ enrichment. This is most likely caused by $\mathrm{ZnO}$ diffusion through the periclase matrix of the fused grain (as seen in Figure 8), allowing $\mathrm{ZnO}$ to react with the spinel particles before the periclase matrix dissolves and the spinel particles come into direct contact with the liquid bath, containing both $\mathrm{ZnO}$ and $\mathrm{Al}_{2} \mathrm{O}_{3}$. This interaction between $\mathrm{ZnO}$ from the slag and a magnesia-chromite refractory has also been observed in the case of a $\mathrm{ZnO}$-containing fayalite slag $[27,28]$.

As can be seen in Figures 7 and 8, at the interface between the FG and the slag, only a thin forsterite layer has formed from the reaction between the dissolved $\mathrm{MgO}$ from the periclase phase and the $\mathrm{SiO}_{2}$ present in the slag. As this forsterite layer is relatively thin at the hot face, it will provide little hindrance 
to the dissolution of $\mathrm{MgO}$, as can be corroborated from the floating secondary chromite particles in the slag.

\subsubsection{Slag S2}

Whereas for slag $\mathrm{S} 1$ it could be assumed that the dissolution of the alumina crucible during the test is limited, comparison of the slag composition $\mathrm{S} 2$ in Table 1 with the concentration of $\mathrm{Al}_{2} \mathrm{O}_{3}$ in the amorphous and the spinel phase Sp2 shown in Figure 12, indicates that this is not the case for the slag $\mathrm{S} 2$. Therefore, the phase equilibria resulting from the interaction between the slag $\mathrm{S} 2$ and $\mathrm{Al}_{2} \mathrm{O}_{3}$ has been calculated with FactSage. The result is shown in Figure 19. This calculation indicates that for the measured concentration $\mathrm{Al}_{2} \mathrm{O}_{3}$ in the amorphous phase, which is $\sim 6$ mole\% according to Figure 12 , the total concentration $\mathrm{Al}_{2} \mathrm{O}_{3}$ in the slag is also $\sim 6$ mole\%. However, the calculated composition of the spinel with which this amorphous phase is in equilibrium, should according to the calculation be much poorer in $\mathrm{Al}_{2} \mathrm{O}_{3}$ and much richer in $\mathrm{Fe}_{2} \mathrm{O}_{3}$ than the actually measured spinel composition (Figure 12). This is likely caused by the formation of $\mathrm{Al}_{2} \mathrm{O}_{3}$-rich spinel particles nearby the crucible wall where the slag is saturated with $\mathrm{Al}_{2} \mathrm{O}_{3}$ (As suggested in Figure 17). These $\mathrm{Al}_{2} \mathrm{O}_{3}$-rich spinel particles are then transported into the bulk slag where the lower concentration of $\mathrm{Al}_{2} \mathrm{O}_{3}$ in the liquid phase compared to its concentration at the crucible wall, causes reestablishment of the slag/spinel equilibrium. This assumption of incomplete equilibrium is supported by the diffusion profile of $\mathrm{Al}_{2} \mathrm{O}_{3}$ and $\mathrm{Fe}_{2} \mathrm{O}_{3}$ in the spinel particles measured nearby its surface (Figure 12). Whereas the concentration $\mathrm{Al}_{2} \mathrm{O}_{3}$ decreases towards the surface, it increases for $\mathrm{Fe}_{2} \mathrm{O}_{3}$. This suggests that the composition of the spinel is moving towards the calculated equilibrium, with higher $\mathrm{Fe}_{2} \mathrm{O}_{3}$ and lower $\mathrm{Al}_{2} \mathrm{O}_{3}$ content than experimentally observed. 



Figure 19: Factsage calculations showing the effect of $\mathrm{Al}_{2} \mathrm{O}_{3}$ on phase fraction and the equilibrium composition of the liquid and spinel phase. Based on the measured concentration $\mathrm{Al}_{2} \mathrm{O}_{3}$ in the slag, the concentration $\mathrm{Al}_{2} \mathrm{O}_{3}$ in the slag is estimated to be around 6 mole\%. As the resulting equilibrium spinel composition is not in agreement with the measured composition, it can be concluded that within the slag S2 equilibrium has not yet been reached.

Although equilibrium has not yet been reached in the slag, the presence of sufficient $\mathrm{Fe}_{2} \mathrm{O}_{3}$ and $\mathrm{Al}_{2} \mathrm{O}_{3}$ in the slag, either initially added or coming from the crucible, causes the slag to be spinel saturated. Therefore, the addition of components forming this phase, in this case MgO dissolving from the refractory sample, will result in the formation of new spinel particles. This is illustrated by the FactSage calculation in Figure 18b. For this calculation, 0 to $20 \mathrm{~g} \mathrm{MgO}$ was added to $100 \mathrm{~g}$ slag having the composition as measured on the amorphous phase shown in Figures 11 and 12. From Figure 18b, it can be seen that up to 2 mole\% $\mathrm{MgO}$ can be dissolved in the liquid phase. Further dissolution of $\mathrm{MgO}$ in the slag will lead to the formation of MgO-containing spinel particles. This is the observed spinel layer at the interface between the slag and the FG, as shown in Figures 13 and 14 . The presence of this protective spinel layer completely changes the dissolution mechanisms for MgO. As seen in Figure 14, the $\mathrm{MgO}$ has to diffuse through the spinel layer before it can dissolve into the liquid bath. The result is a much slower chemical degradation for the slag S2 compared to the slag S1. This is further supported by the difference in $\mathrm{MgO}$ content of the slag. 


\subsubsection{Mitigation of refractory lining wear}

These insights on the effect of the slag composition can be used in industrial smelters when the lining wear is controlled by chemical dissolution of the MgO. By modifying the slag composition, to ensure adequate trivalent cations for spinel formation after reaction with the lining, the MgO dissolution will occur indirectly. This will result in a significantly lower dissolution rate and thus a longer lifetime of the smelter.

\subsection{Conclusion}

This paper shows that for $\mathrm{PbO}$ containing slag systems it is possible to reduce the chemical wear rate by the modification of the slag composition. The saturation of the slag in spinel forming trivalent cations results in the formation of a protective layer between the refractory sample and the slag bath at the hot face. This layer slows down the MgO dissolution from the refractory sample in the liquid bath, which was identified as the main chemical degradation mechanism when the slag is in direct contact with the sample. Because the MgO has to diffuse through the protective spinel layer the wear rate decreases, leading to a longer refractory lifetime.

\subsection{Acknowledgements}

This research was supported by the Agency for Innovation by Science and Technology in Flanders and by Umicore (IWT Baekeland mandate 100700). We also gratefully acknowledge support from the Hercules Foundation (project ZW09-09) for the use of the FEG-EPMA system.

\section{References}

1. Taschler, T., Refractory materials for the copper and lead industry. in Tehran International Conference on Refractories. Tehran, Iran 2004: p. 302-319.

2. Köffel, M. and Taschler, T., Refractories for the copper and lead industry, in World of Metallurgy2006. p. 133-143.

3. Malfliet, A., Lotfian, S., Scheunis, L., Petkov, V., Pandelaers, L., Jones, P.T., and Blanpain, B., Degradation mechanisms and use of refractory linings in copper production processes: A critical review. Journal of the European Ceramic Society, 2014. 34(3): p. 849-876.

4. Malfliet, A., Scheunis, L., Jones, P.T., and Blanpain, B., Refractories in copper production, in Treatise on Process Metallurgy, Volume 3: Industrial Processes, 1st Edition, S. Seetharaman, Editor 2013, Elsevier. p. 600-620.

5. Lee, W. and Zhang, S., Melt corrosion of oxide and oxide-carbon refractories. International Materials Reviews, 1999. 44(3): p. 77-104.

6. Petkov, V., Jones, P.T., Boydens, E., Blanpain, B., and Wollants, P., Chemical corrosion mechanisms of magnesia-chromite and chrome-free refractory bricks by copper metal and anode slag. Journal of the European Ceramic Society, 2007. 27(6): p. 2433-2444.

7. Zhang, S., Sarpoolaky, H., Marriott, N.J., and Lee, W.E., Penetration and corrosion of magnesia grain by silicate slags. British Ceramic Transactions, 2000. 99(6): p. 248-255.

8. Kaur, R.R., Swinbourne, D.R., Wadsley, M.W., and Nexhip, C., Comparison of ferrous calcium silicate slag and calcium ferrite slag interactions with magnesia-chrome refractories. Metallurgical and Materials Transactions B-Process Metallurgy and Materials Processing Science, 2011. 42(3): p. 451-459. 
9. Shchekina, T.I., Gramenitskii, E.N., Batanova, A.M., Alfer'eva, Y.O., Sokolov, A.A., Trofimenko, R.A., Pyrikov, A.N., Grigor'ev, B.N., Likhodievskii, A.V., and Us, T.N., Phase formation processes and structural changes in chromite-periclase refractories used during nickel production. Refractories and Industrial Ceramics, 2012. 52(5): p. 363-376.

10. Tereshchenko, D.A., Platonov, A.A., Platonova, G.R., Chaika, E.F., and Maryasev, I.G., General aspects of periclase-chromite refractory wear during nickel production. Refractories and Industrial Ceramics, 2011. 52(3): p. 212-215.

11. Fedorov, M.S., Ertseva, L.N., and Tsymbulov, L.B., Corrosive interaction between slags high in copper and nickel oxides and periclase, periclase-chromite, and chromite refractories. Refractories and Industrial Ceramics, 2005. 46(5): p. 309-314.

12. Poirier, J., Qafssaoui, F., Ildefonse, J.P., and Bouchetou, M.L., Analysis and interpretation of refractory micro structures in studies of corrosion mechanisms by liquid oxides. Journal of the European Ceramic Society, 2008. 28(8): p. 1557-1568.

13. Jansson, S., Brabie, V., and Bohlin, L., Corrosion mechanism and kinetic behaviour of refractory materials in contact with $\mathrm{CaO}-\mathrm{Al}_{2} \mathrm{O}_{3}-\mathrm{MgO}-\mathrm{SiO}_{2}$ slags. in VII International Conference on Molten Slags Fluxes and Salts. The Southern African Institute of Mining and Metallurgy, Johannesburg. 2004: p. 341-347.

14. Yan, S., Sun, S., and Jahanshahi, S., Reactions of dense $\mathrm{MgO}$ with calcium ferrite-based slags at $1573 \mathrm{~K}$. Metallurgical and Materials Transactions B-Process Metallurgy and Materials Processing Science, 2005. 36(5): p. 651-656.

15. Lee, W.E. and Zhang, S., Direct and indirect slag corrosion of oxide and oxide-C refractories. in VII International Conference on Molten Slags Fluxes and Salts. Cape Town, South Africa 2004: p. 309-320.

16. Liu, J., Guo, M., Jones, P.T., Verhaeghe, F., Blanpain, B., and Wollants, P., In situ observation of the direct and indirect dissolution of $\mathrm{MgO}$ particles in $\mathrm{CaO}-\mathrm{Al}_{2} \mathrm{O}_{3}-\mathrm{SiO}_{2}$-based slags. Journal of the European Ceramic Society, 2007. 27(4): p. 1961-1972.

17. Nightingale, S.A., Monaghan, B.J., and Brooks, G.A., Degradation of $\mathrm{MgO}$ refractory in $\mathrm{CaO}-$ $\mathrm{SiO}_{2}-\mathrm{MgO}-\mathrm{FeO} \mathrm{O}_{x}$ and $\mathrm{CaO}-\mathrm{SiO}_{2}-\mathrm{Al}_{2} \mathrm{O}_{3}-\mathrm{MgO}-\mathrm{FeO} \mathrm{O}_{x}$ slags under forced convection. Metallurgical and Materials Transactions B, 2005. 36(4): p. 453-461.

18. Jak, E. and Hayes, P.C., Experimental study of phase equilibria in the $\mathrm{PbO}-\mathrm{ZnO}-{ }^{\prime \prime} \mathrm{Fe}_{2} \mathrm{O}_{3}$ "-CaO$\mathrm{SiO}_{2}$ system in air for high lead smelting slags $\left(\mathrm{CaO} / \mathrm{SiO}_{2}=0.35\right.$ and $\mathrm{PbO} /\left(\mathrm{CaO}+\mathrm{SiO}_{2}\right)=5.0$ by weight). Metallurgical and Materials Transactions B-Process Metallurgy and Materials Processing Science, 2002. 33(6): p. 817-825.

19. Scheunis, L., Campforts, M., Jones, P.T., Blanpain, B., and Malfliet, A., The influence of slag compositional changes on the chemical degradation of magnesia-chromite refractories exposed to PbO-based non-ferrous slag saturated in spinel. Journal of the European Ceramic Society, 2015. 35(1): p. 347-355.

20. Jak, E., Degterov, S., Zhao, B., Pelton, A., and Hayes, P., Coupled experimental and thermodynamic modelling study of the system $\mathrm{PbO}-\mathrm{ZnO}-\mathrm{FeO}-\mathrm{Fe}_{2} \mathrm{O}_{3}-\mathrm{CaO}-\mathrm{SiO}_{2}-\mathrm{Al}_{2} \mathrm{O}_{3}$ for lead and zinc smelting. in Zinc and Lead Processing. 1998: p. 313-333.

21. Jak, E. and Hayes, P.C., The effect of the $\mathrm{CaO} / \mathrm{SiO}_{2}$ ratio on the phase equilibria in the $\mathrm{ZnO}$ "Fe $\mathrm{O}_{3}{ }^{\prime \prime}-\left(\mathrm{PbO}+\mathrm{CaO}+\mathrm{SiO}_{2}\right)$ system in air: $\mathrm{CaO} / \mathrm{SiO}_{2}=0.1, \mathrm{PbO} /\left(\mathrm{CaO}+\mathrm{SiO}_{2}\right)=6.2$, and $\mathrm{CaO} / \mathrm{SiO}_{2}=0.6$, $\mathrm{PbO} /\left(\mathrm{CaO}+\mathrm{SiO}_{2}\right)=4.3$. Metallurgical and Materials Transactions B-Process Metallurgy and Materials Processing Science, 2003. 34(4): p. 369-382.

22. Jak, E. and Hayes, P.C., Experimental liquidus in the PbO-ZnO-" $\mathrm{Fe}_{2} \mathrm{O}_{3} "-\left(\mathrm{CaO}+\mathrm{SiO}_{2}\right)$ system in air, with $\mathrm{CaO} / \mathrm{SiO}_{2}=0.35$ and $\mathrm{PbO} /\left(\mathrm{CaO}+\mathrm{SiO}_{2}\right)=3.2$. Metallurgical and Materials Transactions BProcess Metallurgy and Materials Processing Science, 2002. 33(6): p. 851-863.

23. Jak, E., Hayes, P.C., Degterov, S., Pelton, A.D., and Wu, P., Thermodynamic optimization of the systems $\mathrm{PbO}-\mathrm{SiO}_{2}, \mathrm{PbO}-\mathrm{ZnO}, \mathrm{ZnO}-\mathrm{SiO}_{2}$ and $\mathrm{PbO}-\mathrm{ZnO}-\mathrm{SiO}_{2}$. Metallurgical and Materials Transactions B, 1997. 28(6): p. 1011-1018. 
24. Bale, C.W., Chartrand, P., Degterov, S.A., Eriksson, G., Hack, K., Ben Mahfoud, R., Melancon, J., Pelton, A.D., and Petersen, S., FactSage thermochemical software and databases. CalphadComputer Coupling of Phase Diagrams and Thermochemistry, 2002. 26(2): p. 189-228.

25. Bale, C.W., Belisle, E., Chartrand, P., Decterov, S.A., Eriksson, G., Hack, K., Jung, I.H., Kang, Y.B., Melancon, J., Pelton, A.D., Robelin, C., and Petersen, S., FactSage thermochemical software and databases - recent developments. Calphad-Computer Coupling of Phase Diagrams and Thermochemistry, 2009. 33(2): p. 295-311.

26. Scheunis, L., Fallah Mehrjardi, A., Campforts, M., Jones, P.T., Blanpain, B., and Jak, E., The effect of phase formation during use on the chemical corrosion of magnesia-chromite refractories in contact with a non-ferrous $\mathrm{PbO}-\mathrm{SiO}_{2}$ based slag. Journal of the European Ceramic Society, 2014. 34(6): p. 1599-1610.

27. Chen, L., Guo, M., Shi, H., Scheunis, L., Jones, P., Blanpain, B., Malfliet, A., The influence of ZnO in fayalite slag on the degradation of magnesia-chromite refractories during secondary $\mathrm{Cu}$ smelting. Journal of the European Ceramic Society, 2015. 35(9): p. 2641-2650.

28. Chen, L., Guo, M., Shi, H., Huang, S., Jones, P., Blanpain, B., Malfliet, A., The effect of ZnO level in secondary copper smelting slags on slagmagnesia-chromite refractory interactions. Journal of the European Ceramic Society, 2016. 36(7): p. 1821-1828. 